\title{
Co w Polsce wiemy o blokadzie Leningradu?
}

What do Poles Know About the Siege of Leningrad?

\begin{abstract}
Aвstract: This article presents a broad commentary on the translation of parts of the book The Ethics of the Siege of Leningrad: The Concept of Morality in Leningrad in 1941-1942 [Блокадная этика: представление о морали в Ленинграде в 1941-1942 гг.] by Sergey Yarov. The author shows how representations of the siege have changed in post-war Russia, especially since the collapse of the Soviet Union. Against this background, the author discusses Polish publications on this subject.
\end{abstract}

KEY wORDs: the siege of Leningrad, humanitarian catastrophe, Sergey Yarov, microhistory, (post)memory

Mówiąc podczas wizyty w Polsce w 2014 roku o znaczeniu blokady Leningradu w historii Rosji, petersburska historyczka Julia Kantor uznała oblężenie za jedną „z największych historycznych traum Rosji”. Podkreśliła przy okazji dokonującą się stopniowo, acz konsekwentnie, po rozpadzie ZSRR zmianę w odbiorze tej tragedii. Narrację o Leningradzie jako mieście-bohaterze, sowieckim symbolu heroizmu zaczyna jej zdaniem zastępować postrzeganie oblężonego miasta niemal jako obozu koncentracyjnego ${ }^{2}$ czy miejsca męczeństwa i katastrofy humanitarnej. Wśród wielu nad wyraz ciekawych wątków poruszanych przez publicystkę znalazł się między innymi problem wzajemnej świadomości historycznej Polaków i Rosjan, w tym szczególnie młodego pokole-

\footnotetext{
${ }^{1}$ Przyślijcie cukierki. Z Julią Kantor, rosyjską historyczką i publicystką, rozmawia Justyna Prus-Wojciechowska. „Nowa Europa Wschodnia” 2014, nr 2. Dostępne w Internecie: http://www. new.org.pl/1798-przyslijcie-cukierki [data dostępu: 16.07.2020].

2 Por. tamże.
} 
nia $^{3}$ i, co za tym idzie, perspektyw wynikających z porównywania takich doświadczeń granicznych, jak blokada Leningradu i powstanie warszawskie czy powstanie w getcie warszawskim. Porównań, dodajmy, które zdaniem Kantor nie mają właściwie sensu.

Abstrahując od kategorycznych sądów petersburskiej historyczki, warto przyjrzeć się polskiej świadomości blokady Leningradu i coraz częstszej, intensywniejszej obecności oblężenia w tekstach naukowych i (post)pamięciowych, a przy okazji zastanowić się nad jego z jednej strony unikalnością, a z drugiej - uniwersalnością. Nie da się bowiem myśleć o wspólnocie losów, do której nawołuje Kantor, bez znajomości obu kontekstów, ale i bez podejmowania prób porównań, szukania punktów stycznych, gdy mowa chociażby o losie cywilów, ich roli - nierzadko milczących świadków, biernych obserwatorów - czy o tak trudnym zagadnieniu, jak analiza ich postaw etycznych. W tym kontekście książka Siergieja Jarowa (1959-2015) Блокадная этика. Представления о морали в Ленинграде в 1941-1942 г2. („Etyka blokady. Wyobrażenia o moralności w Leningradzie w latach 1941-1942”), wydana po raz pierwszy w 2011 roku, poświęcona normom obyczajowym i moralności oblężonych, mogłaby stać się dobrym punktem wyjścia do badań porównawczych. Okazałoby się wówczas, że w przypadku różnych sytuacji granicznych istnieją podobne mechanizmy zachowań będące rezultatem głodu, chłodu, strachu, cierpienia.

W kontekście publikacji nieżyjącego już historyka, który na etapie przygotowywania prac o etyce i codzienności oblężonego Leningradu przeczytał setki dzienników, zapisków różnych mieszkańców tego miasta, wyraźnie widać zwrot dokonujący się także w badaniach nad blokadą Leningradu. Polega on właśnie na ujęciu mikrohistorycznym, odrzuceniu wielkonarracyjnego tonu na rzecz badania - jak określiliby to Rosjanie - „małego człowieka” i jego otoczenia. „Mały człowiek” (маленький человек) to szczególna kategoria, znana dotychczas przede wszystkim historykom literatury, zwłaszcza rosyjskiej klasyki XIX wieku, analizującym utwory Nikołaja Gogola czy Fiodora Dostojewskiego. Jej pojawienie się w kontekście badań historycznych wyznaczyło nowe perspektywy poznawcze, przede wszystkim włączenie do badań świadectw cywilów, mało wiarygodnych dotąd dla profesjonalnych badaczy obserwatorów wydarzeń dziejących się na obrzeżach wielkiej historii. W przypadku Leningradu oznacza to chociażby nie tyle odrzucenie, ile istotne uzupełnienie dotychczasowych, często „wygładzonych” przez radziecką cenzurę wspomnień (na przykład żołnierzy biorących udział $\mathrm{w}$ walkach na froncie leningradzkim) bezpośrednimi zapiskami, relacjami mieszkańców oblężonego miasta.

Co ciekawe, do najważniejszych patronów i prekursorów zwrotu mikrohistorycznego należy właśnie żołnierz Armii Czerwonej, uczestnik walk w czasie

${ }^{3}$ Symptomatyczne jest, że według historyczki rosyjscy studenci więcej wiedzą „o wojennych losach Polski" niż Polacy o blokadzie Leningradu. Zob. tamże. 
wielkiej wojny ojczyźnianej Daniił Granin, który wraz z Alesiem Adamowiczem stworzył Księgę blokady, tj. dowód oskarżenia, składający się z opowieści będących potwierdzeniem przerwania tamy milczenia, ale i głębokiej rany, piętna odciskającego się zarówno na ciele, jak i w psychice ocalonych. W Księdze... po raz pierwszy mówi się o codziennym heroizmie, ale i tragizmie, poświęceniu oraz, z drugiej strony, hańbie i upodleniu. Księga blokady została wydana w Polsce dwukrotnie, tj. w 1982 oraz 1988 roku, i nawet w wersji ocenzurowanej ${ }^{4}$ wywołuje ona ogromne emocje odbiorców. Siła jej przekazu wynika głównie $\mathrm{z}$ autentyczności, otwartości rozmówców Granina i Adamowicza. Mimo początkowej niechęci, a czasami wręcz wrogości wynikającej ze strachu, a nierzadko poczucia wstydu oblężonych, autorom udało się zebrać ogromny materiał dwieście nagranych opowieści ${ }^{5}$ przełożyło się na 4000 stron maszynopisu. Za niezmiernie ciekawy, ale i szalenie ważny w kontekście upamiętnienia oblężenia i Ksiegi blokady oraz podkreślenia niezwykłej siły przekazu tego dzieła uznać należy film Czytając „Księgę blokady” Aleksandra Sokurowa ${ }^{6}$.

Warto tutaj zapytać, czy polski czytelnik ma szansę w ogóle zaobserwować ten mikrohistoryczny zwrot $\mathrm{w}$ przypadku oblężenia Leningradu. I do jakich publikacji o blokadzie może dotrzeć? Okazuje się, że jeśli chodzi o świadectwa, to sytuacja na tym polu nie jest najgorsza. W rozszerzaniu wiedzy o blokadzie Leningradu w polskim obiegu czytelniczym niebagatelną rolę odgrywa fakt, że w ostatnich latach pojawiły się istotne uzupełnienia kanonicznych tekstów Księgi blokady, tj. paralelne, można by rzec, świadectwa. Do zapisków nastoletniego Jury Riabinkina dołączył Dziennik czasu blokady Leny Muchiny ${ }^{7}$, relację Lidii

${ }^{4}$ Nie mogło być inaczej, ponieważ pełne, nieocenzurowane wydanie pojawiło się w Rosji dopiero w 2013 r. Zob. A. Adamowicz, D. Granin: Księga blokady. Przeł. W. Bieńkowska. Warszawa 1982; wyd. II - 1988. Z kolei w 2011 r. ukazał się polski przekład anglojęzycznej edycji - A. Adamowicz, D. Granin: W oblężonym Leningradzie. Dramatyczne wspomnienia. Przeł. A. Wrzosek. Warszawa 2011.

${ }^{5}$ Ten rodzaj kontaktu ze świadkami i pracy nad tekstem przejmie później Swietłana Aleksijewicz, autorka takich książek, jak: Wojna nie ma w sobie nic z kobiety, Cynkowi chłopcy, Czarnobylska modlitwa. Kronika przyszłości czy Czasy secondhand. Koniec czerwonego człowieka. Jej utwory, określane mianem powieści polifonicznych, powieści-oratoriów, powieści zbiorowych, stały się rozpoznawalne na całym świecie, co doprowadziło do przyznania tej pisarce Literackiej Nagrody Nobla w 2015 r. W uzasadnieniu Akademia Szwedzka podkreśliła, że polifoniczne pisarstwo Aleksijewicz to "pomnik cierpienia i odwagi”.

${ }^{6}$ Por. B. Pawletko: Blokada Leningradu i jej reprezentacje w świetle innych doświadczeń granicznych. Katowice 2016, s. 281-284. Dla Sokurowa temat ten jest na tyle ważny, że jego ślady odnajdziemy i w takich filmach, jak Rosyjska arka oraz Frankofonia. Więcej na ten temat zob. rozdział „Rosyjska arka” i „Frankofonia” Aleksandra Sokurowa jako reprezentacje (post)pamięci o blokadzie Leningradu pomieszczony w książce B. Pawletko, B. Waligórskiej-Olejniczak: Wspótczesne kino rosyjskie w obliczu traum wojennych. Kontekst literacki i kulturowy. Katowice 2020, s. 101-124.

${ }^{7}$ L. Muchina: Dziennik czasu blokady. Zapiski nastolatki z oblężonego Leningradu. Przeł. A. Wołodźko-Butkiewicz. Warszawa 2014. 
Ochapkiny, matki i żony, uzupełniają z kolei zapiski nauczycielki, żony i matki, Jeleny Koczyny, pomieszczone w zbiorze Oblężone.

Wydany dwukrotnie (w 2011 i 2013 roku) tom Oblężone ${ }^{8}$ ważny jest jeszcze z innego powodu. Oprócz świadectwa Koczyny zawiera on bowiem fragmenty notatek dwóch kobiet, które przeżyły oblężenie Leningradu i które w zupełnie różny sposób sygnalizują oraz zapisują psychiczną i cielesną traumę tego doświadczenia. Mowa o Oldze Bergholc oraz Lidii Ginzburg. Zapiski Ginzburg to świadectwo uczonej, literaturoznawczyni, stąd ich wyraźnie obiektywizujący, syntetyzujący charakter, przejawiający się już chociażby w tytule - Zapiski człowieka oblężonego. Z kolei diariusz poetki i najważniejszego kobiecego głosu leningradzkiego radia w trakcie trwania blokady, Olgi Bergholc, zdradza ogromny ładunek emocjonalny i bezkompromisowość w ocenie działań władzy - jest to bowiem fragment Zakazanego dziennika, który został opublikowany dopiero w 2011 roku. Słabą stroną zbioru Oblężone jest jednak to, że mamy w nim do czynienia jedynie z fragmentami utworów Bergholc i Ginzburg, co zaburza spójność i przejrzystość ich przekazu, osłabiając przy okazji siłę tych głosów. Podobna sytuacja ma zresztą miejsce w przypadku dziennika badaczki literatury antycznej i mitologii Olgi Frejdenberg, który w niepełnej formie, wraz z wzajemną korespondencją między uczoną i jej kuzynem Borysem Pasternakiem, ukazał się w serii Wydawnictwa Sedno?.

Wymienione publikacje nie tylko przynoszą przełom w kwestii deficytu kobiecych narracji, ale przede wszystkim wskazują na specyfikę sytuacji w oblężonym mieście, na którą zwrócił uwagę Granin. Mowa o niezwykłej roli inteligencji podczas blokady. To właśnie inteligenci stanowią najliczniejszą, a przy tym najbardziej rozpoznawalną i reprezentatywną grupę wśród kronikarzy oblężenia. Potwierdzeniem tej tezy są jeszcze dwa świadectwa, do których może dotrzeć polski czytelnik, a mianowicie diariusz historyka Gieorgija Kniaziewa stanowiący część Księgi blokady oraz Wspomnienia filologa i kulturologa Dmitrija Lichaczowa, wydane w tej samej serii, co korespondencja Frejdenberg i Pasternaka ${ }^{10}$. Przy okazji warto wspomnieć, że badaniem roli inteligencji podczas blokady zajmuje się zwłaszcza Polina Barskowa, badaczka urodzona w Leningradzie w 1976 roku i od wielu lat mieszkająca w Stanach Zjednoczonych. Poddaje ona blokadę Leningradu nie tylko refleksji naukowej. Znany jest jej utwór Жuвbıe картины („Żywe obrazy”) z 2014 roku, którego akcja toczy się w Ermitażu podczas oblężenia, oraz działania na rzecz popularyzacji blokady wśród młodego pokolenia, wyrażające się w stworzeniu chrestomatii Блокада. Свидетельства о тенинградской блокаде. Хрестоматия („Blokada. Świadectwa o blokadzie

${ }^{8}$ Oblężone. Przeł. A. Knyt, E. Milewska-Zonn. Wybór i oprac. A. Knyt. Warszawa 2011; wyd. II - 2013.

${ }^{9}$ O. Frejdenberg, B. Pasternak: Na całe życie: listy 1910-1954. Przeł. W. Grajewski. Warszawa 2014.

${ }^{10}$ D. Lichaczow: Wspomnienia. Przeł. B. Żyłko. Warszawa 2016. 
Leningradu. Chrestomatia", 2017) przeznaczonej dla uczniów. Znaleźć w niej można reprezentatywne teksty utrwalające sytuację oblężonego miasta. Oprócz działań wydawniczych i popularyzatorskich ${ }^{11}$ Barskowa opublikowała wiele rozproszonych jak na razie tekstów z pogranicza literaturoznawstwa, kulturoznawstwa i antropologii, poświęconych różnym odsłonom i postaciom oblężonego Leningradu; szkice te docelowo mają się złożyć na monografię.

Jeśli chodzi o kompleksowe rosyjskie opracowania dotyczące blokady, jest to zdecydowanie domena historyków. Oprócz Jarowa do najbardziej znanych badaczy oblężenia należy Nikita Łomagin - autor książek i artykułów o blokadzie, który zajmuje się przede wszystkim jej ekonomicznymi i społeczno-politycznymi konsekwencjami. Ciekawą i ważną publikacją jest monografia Tatiany Woroniny z 2018 roku Помнить по-натему. Соиреалистический историзм и блокада Ленинграда („Pamiętać z naszej perspektywy. Historyzm socrealistyczny i blokada Leningradu"). Woronina to uczennica Jarowa, która śledzi ewolucję powojennej recepcji i interpretacji blokady Leningradu. Kluczem do napisania jej książki było pojęcie polityki pamięci, która w określony sposób wpływała na postrzeganie oblężenia i publikację utworów zgodnych z kanonem socrealistycznym, postulującym unikanie tematów drażliwych, propagującym klisze językowe i propagandowe oraz kładącym nacisk na heroizację opisywanych wydarzeń. Widać to było na przykład w publikacjach rocznicowych, tematycznych numerach czasopism literackich, takich jak "Znamia”, „Newa”, „Zwiezda”. Na szczęście, w latach 90. XX wieku oraz w pierwszej dekadzie XXI wieku te same i jeszcze inne periodyki (na przykład „Nowoje litieraturnoje obozrienje”, „Nieprikosnowiennyj zapas") zaczną upowszechniać najpierw rozliczeniowe teksty i świadectwa, zatrzymane niegdyś przez cenzurę, a potem archiwalia, publikacje o charakterze (post)pamięciowym oraz studia badaczy uwzględniających $\mathrm{w}$ pogłębionych analizach oblężenia narzędzia odnoszące się do najnowszych tendencji i nurtów badawczych, takich jak trauma studies, memory studies, teoria afektu i inne ${ }^{12}$.

Siergiej Jarow natomiast najczęściej porusza się w kręgu zagadnień psychologii historycznej. W jej ramach bada się między innymi medyczne konsekwencje blokady w drugim i trzecim pokoleniu, takie jak „zaburzenia przemiany materii czy

${ }^{11}$ Warto tu jeszcze odnotować najnowsze publikacje Barskowej - w 2019 r. ukazał się zbiór Блокадные после (Москва), а ш 2020 Седьмая щелочь: тексты и судьбы блокадных поэтов (Санкт-Петербург).

${ }^{12}$ Jak zauważa Siergiej Uszakin, tendencja do powstawania nowych praktyk analitycznych, obejmujących badania nad codziennością, historią mówioną i innymi świadectwami, traumą, pamięcią i afektami, pojawia się najpierw w badaniach nad Holokaustem, a następnie przejęta zostaje przez badaczy innych doświadczeń granicznych, w tym blokady Leningradu. Zob. С. Ушакин, Е. Махотина, М. Габович, Н. Ломагин, Д. Хлевнюк, Л. Киршенбаум, И. Сандомирская: Память о блокаде, блокада памяти. «Неприкосновенный запас» 2019, 5. https://magazines. gorky.media/nz/2019/5/pamyat-o-blokade-blokada-pamyati.html [22.07.2020]. 
bardzo słabe zęby"13. Autor skupia się jednak także na psychicznych konsekwencjach głodu i bombardowań. Zajmując się historią, a właściwie, jak to określa Julia Kantor, anatomią blokady, tj. odsłaniając przerażające fakty dotyczące upadku norm etycznych oraz rozpadu więzi rodzinnych i społecznych w oblężonym mieście, kradzieży jedzenia i kartek żywnościowych, szabrownictwa, przemocy psychicznej i fizycznej, wreszcie kanibalizmu, sam Jarow również padł ofiarą choroby. Podobne doświadczenia stały się zresztą wcześniej udziałem Adamowicza i Granina. Publicystka wspomina, że historyk bardzo wychudł i posiwiał, a jego śmierć w wieku 56 lat była ogromnym zaskoczeniem. W jednym $\mathrm{z}$ wywiadów Jarow potwierdził, że z tysięcy dokumentów, które przeanalizował, w pamięci utrwaliły mu się najtragiczniejsze epizody, między innymi dotyczące kanibalizmu wśród uczniów szkół zawodowych, najczęściej przybyszów z różnych zakątków ZSRR, którzy po zamknięciu pierścienia blokady, z dala od rodziny, zostali zdani na własne siły. Temat ten w przypadku Jarowa ma drugie - autobiograficzne, ale i afektywne - dno. Okazuje się bowiem, że historyk był wychowankiem domu dziecka, dlatego w wywiadach dość często nawiązywał do miejsc, gdzie obecnie toczy się normalne życie, a wcześniej znajdowała się kostnica albo internat szkoły zawodowej, w którego piwnicy dochodziło do aktów kanibalizmu wśród nieletnich. W ten sposób - sygnalizuje Jarow - topografia katastrofy utrwala się w człowieku na tyle głęboko, że nie jest on już w stanie, przechodząc tą czy inną ulicą, nie myśleć o ofiarach i wydarzeniach, które miały tam miejsce ${ }^{14}$.

Co ciekawe, temat blokady pojawił się w kręgu zainteresowań Siergieja Jarowa bardzo późno, właściwie w ostatnich dziesięciu latach życia, kiedy był on

${ }^{13}$ Przyślijcie cukierki...

${ }^{14}$ Por. fragment wywiadu Jarowa z Katieriną Gordiejewą: „Mam w pamięci wszystkie te dokumenty, tę piwnicę, całą tę historię. I nie mogę się od nich uwolnić. One tam zamieszkały na dobre. Właśnie te tragiczne momenty zapadają w pamięć najgłębiej. Nie uroczystości, nie saluty, parady, tylko te bolesne szczegóły. I do tego konkretne adresy. Na rogu ulicy Niekrasowa i Litiejnego Prospektu nastolatek prosi o jałmużnę. Widzę to jak dziś. Dla mnie blokada, cała ta katastrofa zyskała bardzo konkretny wymiar topograficzny. I to się już nie zmieni” ( Они у меня в голове поселились и живут». Интервью Катерины Гордеевой с Сергеем Яровым. http:// www.sinergia-lib.ru/index.php?page=yarov_s_v [21.07.2020]. Tłumaczenie moje - B.P.). Istotę niepewności, niepokoju, dylematów towarzyszących współczesnemu człowiekowi w konfrontacji z takimi miejscami nieistnienia trafnie ujął Paweł Próchniak: „Miejsca nieistnienia to miejsca rany, nieme blizny pamięci, usunięte z żywej świadomości, ale wciąż ropiejące gdzieś na jej obrzeżach, rzucające głęboki, niepokojący cień, bolesne i dlatego omijane. [...] Obecności takich miejsc w naszym świecie niełatwo jest sprostać. Ich niepewna ontologia jest na wskroś paradoksalna - są zarazem przeklęte i święte, w najwyższym stopniu przerażające i całkowicie zwyczajne. W oczywisty sposób istnieją, ale jednocześnie na różne sposoby ich nie ma. Nie ma ich, choć przecież byliśmy w nich. Patrzyliśmy na nie. Dotykaliśmy ran, które po nich pozostały. I wciąż niesiemy je w sobie. To dlatego niekiedy jeszcze krwawią. Dlatego wychylają się w nasz świat. Dlatego bolą" (P. Próchniak: Miejsca nieistnienia (wypisy). W: Pamięć i afekty. Red. Z. Budrewicz, R. Sendyka, R. Nycz. Warszawa 2014, s. 491, 493; por. również tekst Romy Sendyki: Miejsca, które strasza (afekty i nie-miejsca pamięci) pomieszczony w tym samym tomie na s. 285-307). 
już doświadczonym, w pełni ukształtowanym badaczem. Wcześniej zajmował się ruchem rewolucyjnym i jego następstwami, analizując zwłaszcza pierwsze lata po rewolucji, tj. okres wojny domowej, komunizmu wojennego w Piotrogrodzie, a także początki NEP-u. Tak się składa, że był to czas nie tylko politycznego fermentu, zawirowań, ale przede wszystkim głodu, do którego mieszkańcy oblężonego miasta (szczególnie starsi) często dostrzegali analogie. W odniesieniu do badania ruchu robotniczego, refleksji nad mieszkańcami Piotrogrodu i rosyjskimi chłopami psychologia historyczna przydała się Jarowowi w zgłębianiu rozwijającej się świadomości politycznej, zmieniających się nastrojów społeczno-politycznych różnych grup społecznych (chłopi, proletariusze, inteligenci), problemów konformizmu, ale i oporu, propagandy, agitacji oraz bolszewizacji języka codziennego. Pozostawał zatem Jarow w kręgu kwestii związanych z miastem nad Newą, podążając jednocześnie w stronę interdyscyplinarności. W jego pracach widoczne jest zacięcie socjologiczne, psychologiczne i politologiczne ${ }^{15}$.

„Etyka blokady...” ukazała się po raz pierwszy w 2011 roku (kolejne wydania - 2012 i 2013), z kolei Повседневная жизнь блокадного Ленинграда („Żyсіе codzienne oblężonego Leningradu" ${ }^{16} \mathrm{w}$ roku 2013. W pierwszej książce Jarow bazuje zarówno na oficjalnych dokumentach, jak i dziennikach, wspomnieniach, listach oblężonych. Historyk otrzymał za nią nagrodę im. Nikołaja Ancyfierowa (międzynarodowa nagroda przyznawana za prace poświęcone Petersburgowi). Drugie opracowanie ma charakter popularnonaukowy i dotyczy życia codziennego mieszkańców oblężonego miasta. Ta publikacja przyniosła autorowi nagrodę „Proswietitiel”. Ważne, że jest to wyróżnienie w dziedzinie literatury, która ma za zadanie przyciągnąć uwagę zwykłych czytelników, kierując ją w stronę opracowań naukowych. O książkach Jarowa często wspomina się w kontekście Księgi blokady, podkreślając wagę zgromadzonych przez niego źródeł, szczególnie nieprofesjonalnych, pochodzących z archiwów egodokumentów (listów, zapisków, diariuszy), które w zupełnie innym świetle niż historiograficzny kanon ukazują codzienność oblężonego miasta oraz jego mieszkańców, ich obyczaje, stare i nowe, wypracowane w trakcie pierwszej zimy nawyki, konieczność oswajania nieznanej rzeczywistości. To źródła, które mówią same za siebie, w których nie ma miejsca na fałsz, patos, a ponieważ jest ich naprawdę wiele, stąd - podkreśla Jarow - traumatyczny efekt, jaki wywołują u odbiorcy, również profesjonalnego.

Część z wykorzystywanych w trakcie pracy nad monografiami materiałów źródłowych została już wcześniej opublikowana. Jednak o nowatorstwie i oryginalności dokonań historyka świadczą teksty mało znane lub w ogóle nieznane, które Jarow sam najpierw odnalazł w archiwach, przyswoił, a potem wykorzystał, by pokazać tragedię miasta i jego mieszkańców. Przede wszystkim są to dzienniki

${ }_{15}$ Por. А. Алексеев: Человек, родившийся после войны, но эту войну переживщий. http:// www.cogita.ru/a.n.-alekseev/andrei-alekseev-1/chelovek-rodivshiisya-posle-voiny-no-etu-voinuperezhivshii [12.07.2020].

${ }^{16}$ С. Яров: Повседневная жизнь блокадного Ленинграда. Москва 2013. 
oblężonych, szczególnie robotników, ludzi niewykształconych. Do nich Jarow odwołuje się równie często, co do świadectw literackich. Wśród tych ostatnich nie brak tekstów Dmitrija Lichaczowa, Olgi Bergholc czy Lidii Ginzburg. Aleksandr Dmitriew zwraca uwagę na fakt, że autorowi „Etyki blokady...” udaje się $\mathrm{z}$ powodzeniem łączyć w toku płynnej narracji różne dokumenty: $\mathrm{z}$ jednej strony są to właśnie wspomnienia, prywatne zapiski i listy, z drugiej - dokumenty oficjalne, i to zarówno jawne, jak i tajne ${ }^{17}$. Badacz podkreśla szczególną umiejętność Jarowa, historyka rewolucji, by w obszernych oficjalnych dokumentach (na przykład protokołach), często napisanych niezrozumiałym językiem, wskazać esencję, samą ich istotę, ale wykorzystać także miejsca niespójne, podkreślające chęć zamaskowania prawdy. Dmitriew słusznie zresztą sugeruje, że język protokołów z zebrań to często efekt pracy bohaterów poprzednich tekstów Jarowa, a więc ludzi tworzących struktury władzy komunistycznej, którymi zajmował się wcześniej. Historyk znał ich kształtującą się po rewolucji mentalność, tożsamość, mechanizmy myślenia, zachowania, również sposób wyrażania. Jarow stworzył zatem syntetyczny sposób pisania, daleki od wyrafinowanego, abstrakcyjnego stylu najnowszych publikacji z dziedziny historii, historiografii, teorii historii. Nie ma tu odwołań do ustaleń historyków i teoretyków zachodnich, chociaż można dostrzec analogie do kategorii wykorzystywanych podczas analizy mechanizmów zachowań w przypadku innych doświadczeń granicznych, na przykład więźniów nazistowskich lagrów. Dmitriew wspomina w tym kontekście chociażby dzieła więźnia Auschwitz Prima Leviego oraz prace filozofa Giorgia Agambena ${ }^{18}$. Aby podkreślić szeroką skalę dziejących się w mieście wydarzeń, historyk nie lekceważy żadnego ze źródeł, traktując opowieści oblężonych na równi z zapisem protokołów i dyrektyw władz partyjnych czy miejskich. Jest przy tym niezwykle wyczulony na detale, niuanse, na zapis myślenia kolektywnego i indywidualnego. Źródła są dla niego najważniejsze. To przede wszystkim one mówią w jego pracach, stąd być może spora popularność tych studiów również wśród nieprofesjonalnych czytelników.

O randze dokonań Jarowa świadczą nie tylko wznowienia jego książek, ale też fakt, że w 2017 roku „Etyka blokady...” została wydana w języku angielskim $^{19}$. W Polsce dotychczas nie przełożono żadnej z jego prac. Wzmianki o historyku blokady pojawiają się jedynie w specjalistycznych opracowaniach akademickich ${ }^{20}$. Wracając do obecnych na polskim rynku wydawniczym książek o oblężeniu, przyznać trzeba, że także prace znacznie bardziej rozpoznawalnego

${ }_{17}$ Por. А. Дмитриев: Сведения и свидетельства: Сергей Яров - историк блокады. «Неприкосновенный запас» 2019, 5. https://magazines.gorky.media/nz/2019/5/svedeniya-i-svi detelstva-sergej-yarov-istorik-blokady.html [21.07.2020].

18 Por. tamże.

${ }^{19}$ S. Yarov: Leningrad, 1941-42: Morality in a City under Siege. Transl. A. Tait. Cambridge, UK-Malden, US 2017.

${ }^{20}$ Zob. B. Pawletko: Blokada Leningradu..., s. 54-59. 
na Zachodzie historyka blokady Nikity Łomagina nie znalazły się w centrum zainteresowania polskich wydawców. Mamy tu zatem do czynienia z przedziwną sytuacją. W Polsce o historii blokady więcej można dowiedzieć się właściwie jedynie z artykułów prasowych lub książki angielskiej dziennikarki Anny Reid Leningrad. Tragedia oblężonego miasta 1941-194421. Najnowszym potwierdzeniem tej smutnej konstatacji pozostaje wydany w 2019 roku tom amerykańskiej historyczki Alexis Peri Leningrad. Dzienniki $z$ oblężonego miasta ${ }^{22}$, w którym autorka zgromadziła 125 nieopublikowanych dzienników mieszkańców Leningradu, odwołując się przy tym nie tylko do prac Siergieja Jarowa, ale również do innych źródeł. Nie zmienia to jednak faktu, że polski odbiorca nie ma możliwości zapoznania się ze specyfiką ujęć rosyjskich historyków.

W ostatnich latach, między innymi za sprawą działalności Jarowa ${ }^{23}$, obserwujemy w Rosji prawdziwy wysyp tekstów i projektów postmemorialnych o oblężeniu. Ważnym ich aspektem pozostają nie tylko kwestie związane z etyką blokady, ale przede wszystkim z etyką i estetyką pisania o oblężeniu z perspektywy świadka, jego spadkobiercy czy depozytariusza pamięci ${ }^{24}$. Nie mniej istotne w kontekście pytań o to, czy i jak świadczyć w imieniu świadków, są techniczne możliwości (od)tworzenia realiów, symboli oblężonego miasta. Nie sposób wreszcie pominąć afektywnych uwarunkowań narracji, poruszania się po grząskim gruncie silnych uczuć i reakcji - w pierwszej kolejności wstydu, wstrętu oraz strachu. Przyglądając się wzmożonemu zainteresowaniu blokadą, można zauważyć, że w obszarze postpamięci pojawiają się - wywołane zarówno pobudkami osobistymi, rodzinnymi, jak i pozarodzinnymi, zawodowymi, hobbystycznymi - różne ujęcia tej kwestii. Jedni twórcy, jak na przykład Jelena Czyżowa, uczynili z oblężenia stały punkt odniesienia, krążąc nieustannie wokół tego tematu w kolejnych projektach ${ }^{25}$. Drudzy długo przymierzali się, by

${ }^{21}$ A. Reid: Leningrad. Tragedia oblężonego miasta 1941-1944. Przeł. W. Tyszka. Kraków 2012. Więcej zob. B. Pawletko: Blokada Leningradu..., s. 19. Tam też zgromadzono bibliografię innych polskich i polskojęzycznych prac poświęconych oblężeniu Leningradu.

${ }^{22}$ A. Peri: Leningrad. Dzienniki z oblężonego miasta. Przeł. G. Siwek. Kraków 2019.

${ }^{23}$ Warto w tym miejscu wspomnieć o projekcie „Прожито” (Przeżyte), czyli centrum badań nad egodokumentami Uniwersytetu Europejskiego w Petersburgu, którego pracownikiem był Jarow. To miejsce, w którym gromadzone są i stopniowo udostępniane szerokiemu gronu odbiorców w formie elektronicznej opracowania rękopisów dzienników, wspomnień i listów. Rozszyfrowywaniem i redakcją naukową tekstów zajmują się specjaliści, wśród których warto wymienić Nikitę Łomagina i Tatianę Woroncową. W dalszej perspektywie twórcy projektu planują rozszerzanie elektronicznego korpusu egodokumentów o literaturę naiwną, prace z dziedziny folkloru, albumy, kroniki, twórczość dziecięcą itp. Więcej zob. https://prozhito.org/ [data dostępu: 20.07.2020].

${ }^{24}$ Odwołuję się tu do określeń pojawiających się w książkach dwóch polskich badaczek Zagłady, tj. Anny Mach i Marty Tomczok: A. Mach: Świadkowie świadectw. Postpamięć zagłady w polskiej literaturze najnowszej. Warszawa-Toruń 2016; M. Tomczok: Czyja dzisiaj jest Zagłada? Retoryka - ideologia - popkultura. Warszawa 2017.

${ }^{25}$ Więcej na temat zob. B. Pawletko: Blokada Leningradu..., s. 255-257; E. Komisaruk: Blokada Leningradu i postpamięć w powieści Jeleny Czyżowej „Город, написанный по памяти”. 
po swojemu, w niestandardowy sposób podjąć próbę upamiętnienia blokady i bliskich. Do takich twórców z pewnością należy Olga Ławrientjewa, rysowniczka, graficzka, twórczyni komiksów historyczno-dokumentalnych, spośród których na szczególną uwagę zasługuje powieść graficzna „Surwiło” (2019) ${ }^{26}$. Tytuł odsyła do nazwiska dziadka autorki i wsi, z której się wywodził27. Można powiedzieć, że Ławrientjewa to przykład artystki, która wpisuje się w międzypokoleniową transmisję traumy, gdyż „Surwiło” to opowieść rodzinna, opowieść o babci, Walentinie Surwiło, kobiecie, która przeżyła piekło blokady Leningradu, a wcześniej represje stalinowskie, co w konsekwencji doprowadziło do towarzyszącej jej nieustannie trwogi o losy najbliższych. Pretekstem do powstania komiksu były wspomnienia babci o tym, jak traumy dzieciństwa i młodości przekładają się na obecny do końca życia paraliżujący strach o to, że bliscy mogą nagle zniknąć, nie wrócić do domu. Warto podkreślić, że chociaż Ławrientjewa pracuje w obszarze gatunków kojarzonych z popkulturą, to jednak najważniejsza jest dla niej pamięć ludzka, z jej wybiórczością, ulotnością, białymi plamami, a więc i potrzebą jej utrwalania, zapisywania, a także subiektywność odbioru otaczającej rzeczywistości przekładająca się na zapamiętywanie przedziwnych okruchów, najdrobniejszych detali. Dlatego też w jej komiksie nietrudno dostrzec dbałość o precyzyjne oddanie, (od)tworzenie ówczesnych realiów. Ławrientjewa udowadnia, że przekazywane z pokolenia na pokolenie opowieści rodzinne nie tylko odgrywają rolę terapeutyczną, scalającą rodziny, ale stanowią istotną część wiedzy o przeszłości. Temat ten bezsprzecznie zasługuje na większą uwagę, albowiem w historii Walentiny Surwiło jak w soczewce skupiają się koleje losu wielu mieszkańców Związku Radzieckiego, szczególnie w odniesieniu do lat 30. i 40. XX wieku.

Śmiałym, przewrotnym i nowatorskim (zwłaszcza w rosyjskiej przestrzeni kulturowej) nawiązaniem do oblężenia jest film Празднuк (Święto) Aleksieja Krasowskiego, pokazany po raz pierwszy na platformie YouTube 3 stycznia

„Przegląd Rusycystyczny” 2020, nr 3, s. 130-141. O tym, że Czyżowa staje się ekspertką od oblężenia, świadczyć może tekst pisany na zamówienie do szwajcarskiego dziennika "Neue Zürcher Zeitung”, przetłumaczony następnie i wydrukowany zarówno w dodatku do „Rzeczpospolitej” (J. Czyżowa: Zakłamywana pamięć o tragedii i blokadzie Leningradu. „Plus Minus” z 14 września 2019 r. Dostępne także w Internecie: https://www.rp.pl/Plus-Minus/309139981-Jelena-CzyzowaZaklamywana-pamiec-o-tragedii-i-blokadzie-Leningradu.html [data dostępu: 17.07.2020]), jak i w „Gazecie Wyborczej” (Taż: Hitler chciał pokonać Leningrad głodem i zimnem. A Stalin nienawidził tego miasta i nie pomógł oblężonym. „Gazeta Wyborcza” z 13 czerwca 2020 r. Dostępne także w Internecie: https://wyborcza.pl/magazyn/7,124059,26025505,hitler-chcial-pokonac-lenin grad-glodem-i-zimnem-a-stalin.html [data dostępu: 17.07.2020]).

${ }^{26}$ О. Лаврентьева: Сурвило. Санкт-Петербург 2020.

${ }^{27}$ Co ciekawe, mowa jest o wsi w Polsce. Ma to związek z tym, że wioska Surwiło, leżąca w granicach naszego kraju przed zaborami, została ponownie przyłączona do Polski po wojnie polsko-bolszewickiej na mocy traktatu ryskiego z 1921 r. Oprócz guberni grodzieńskiej i wileńskiej dołączono wówczas zachodnie części guberni wołyńskiej oraz właśnie guberni mińskiej. 
2019 roku. Projekt ten obnażył stan świadomości rosyjskiego społeczeństwa, pokutujące wciąż stereotypy, propagandowo-imperialną otoczkę wydarzeń historycznych (przede wszystkim wojennych), przejawiającą się w wystosowywanych pod adresem twórcy oskarżeniach o kalanie świętości, pamięci, brak szacunku dla ofiar. I to wszystko na etapie realizacji filmu, jeszcze przed premierą ${ }^{28}$. Nagonka na reżysera spowodowała nie tylko cofnięcie wsparcia finansowego ze strony państwa i zamknięcie drogi do dystrybucji filmu w kinach, groźby pod adresem Krasowskiego, i to zarówno w przestrzeni wirtualnej, jak i w rzeczywistości realnej, ale również wszczęcie śledztwa w prokuraturze. Reżyser zdecydował się na dokończenie projektu za własne pieniądze, wsparli go też nieliczni sponsorzy, a także na umieszczenie filmu w otwartym dostępie - dowodząc swej niezależności, ale i manifestacyjnie kontestując zasady polityki kulturalnej uprawianej przez władze.

Dlaczego właściwie produkcja Krasowskiego spotkała się jeszcze przed premierą $\mathrm{z}$ tak gwałtownymi reakcjami? Zacznijmy od kwalifikacji gatunkowej. Już sam fakt, że ma powstać czarna komedia o oblężonym Leningradzie, wywołał oburzenie władz, ale i części mediów. Kolejnym punktem spornym okazał się temat filmu, czyli istnienie i funkcjonowanie w oblężonym Leningradzie uprzywilejowanych grup (w tym szczególnie elity partyjnej urzędującej w Instytucie Smolnym, na czele z Andriejem Żdanowem), które bynajmniej nie głodowały, skrzętnie ukrywając przed innymi korzystanie $\mathrm{z}$ wyszukanego $m e n u^{29}$, ale też miały dostęp do wielu innych udogodnień. I po trzecie, nie mniejszy skandal wywołało ogłoszenie przez reżysera, że w zaprezentowanej historii chciał nie tylko skupić się na przeszłości, ale również wskazać na analogie do teraźniejszości, zwrócić uwagę na przywileje różnych grup społecznych we współczesnej Rosji - ludzi bogatych, żyjących ponad stan i czyimś kosztem, oraz na cenzurę, obejmującą zarówno aktualne, jak i przeszłe zagadnienia, między innymi dotyczące nierówności społecznych, niemoralności i uwikłania elit.

Opowiedziana w filmie Krasowskiego historia rodziny mikrobiologa, profesora Aleksieja Woskriesienskiego, który wraz z bliskimi, ale i niespodziewanymi gośćmi świętuje przy pięknie zastawionym stole w noc sylwestrową w komfortowym i okazałym domu znajdującym się nieprzypadkowo na obrzeżach oblężonego miasta - została przez niego wymyślona. Wiadomo jednak, że

${ }^{28} \mathrm{Z}$ podobną sytuacją mieliśmy do czynienia również $\mathrm{w}$ przypadku informacji na temat opracowania Peri. Na autorkę jeszcze nieopublikowanej książki The War Within: Diaries from the Siege of Leningrad posypały się gromy oskarżeń o fałszywe przedstawianie oblężenia. Argumenty polityków i działaczy społecznych, którzy z oczywistych względów nie mogli się zapoznać z monografią amerykańskiej historyczki, przypominały zdaniem Tatiany Woroncowej zimnowojenną narrację. Zob. T. Voroncova: Alexis Peri. The War Within: Diaries from the Siege of Leningrad. MA: Harvard Uniwersity Press, 2017 [review]. „Laboratorium” 2017, nr 9 (3), s. 169-172.

29 Por. Кто ел досыта в блокадном Ленинграде. https://zen.yandex.ru/media/news.ru/ktoel-dosyta-v-blokadnom-leningrade-5c4dbc7b364f1f00acclcdec [28.07.2020]. 
wśród witających rok 1942 leningradczyków wielu znajdowało się już u kresu sił fizycznych, tym bardziej że od 20 listopada do 25 grudnia 1941 roku minimalna dzienna porcja chleba dla pracowników umysłowych oraz osób pozostających na czyimś utrzymaniu wynosiła $125 \mathrm{~g}$, co przełożyło się na rekordową śmiertelność w pierwszych miesiącach nowego roku. Reżyser, pytany o to, z jakich źródeł czerpał wiedzę o sytuacji w oblężonym mieście - warto bowiem zaznaczyć, że choć mamy do czynienia z filmem kameralnym i niskobudżetowym, którego akcja nie wychodzi poza kilka pomieszczeń, to przecież w dialogach postaci nie brakuje kwestii i odniesień do realiów, języka i symboli blokady - wskazuje między innymi książkę Jarowa „Etyka blokady...”, filmy dokumentalne o oblężeniu, a także rozmowy z pracownikami Muzeum Obrony i Blokady Leningradu ${ }^{30}$.

Abstrahując od ocen pomysłu na film, wyboru konwencji gatunkowej, a tym samym zagadnienia granic swobody twórczej (wszak Krasowski nie ukrywa, że jego zamiarem było nie tylko naświetlenie skrywanych wciąż przez władzę tajemnic blokady, lecz również dążenie, by wskazać na analogie między współczesnością a kontekstem oblężenia, co może być z pewnością potraktowane jako niestosowny, zmierzający w stronę banalizacji blokady i zniesienia jej tragicznego decorum eksperyment), jak i od jego wartości artystycznej (trzeba przyznać, że reżyserowi udało się zgromadzić na planie bardzo znanych i szanowanych aktorów oraz uznanego operatora filmowego), warto podkreślić, że twórca Windykatora udowodnił, iż w przypadku oblężonego Leningradu istnieje jeszcze wiele tematów tabu. Chodzi nie tylko o kwestie obyczajowe, społeczne (których zbadania podjął się Jarow), ale przede wszystkim historyczno-polityczne. I im dłużej zamknięte będą archiwa, i nie zostaną udostępnione pewne niewygodne materiały, im rzadziej ważkie zagadnienia oraz dylematy etyczne poddawane będą dyskusji w przestrzeni publicznej, a osobom podejmującym próbę ich omówienia zamykane będą usta (nie mówiąc o takich innych konsekwencjach, jak: brak funduszy, groźby, ostracyzm społeczny, a nawet kary więzienia i łagru), tym częściej zapewne będziemy mieć do czynienia z kolejnymi mitami i przekłamaniami na ten temat.

Nieprzypadkowo w tym pobieżnie zarysowanym i domagającym się większej uwagi oraz aktualizacji przeglądzie najnowszych, postmemorialnych reprezentacji oblężenia znalazły się te dwa projekty, tj. komiks Ławrientjewej i film Krasowskiego. Potwierdzają one zmiany dokonujące się w obrębie form pamięci o blokadzie, dokumentują specyfikę upamiętniania, ale i rozpowszechniania

${ }^{30}$ Więcej zob. А. Долин: На YouTube выходит «Праздник» - комедия про Новый год в блокадном Ленинграде. https://meduza.io/feature/2018/12/31/na-youtube-vyhodit-prazdnikkomediya-pro-novyy-god-v-blokadnom-leningrade-anton-dolin-rasskazyvaet-nad-chem-na-sa mom-dele-smeyutsya-v-filme [28.07.2020]; «Я все выдумал! И надеюсь, что имею на это право в нашей стране». Режиссер Алексей Красовский - о своей комедии «Праздник», действие которой происходит в блокадном Ленинграде. https://meduza.io/feature/2018/10/15/ya-vsevydumal-i-nadeyus-chto-imeyu-na-eto-pravo-v-nashey-strane [27.07.2020]. 
wiedzy o oblężeniu w XXI wieku. Wydają się również symptomatyczne, jeśli chodzi o potencjalne scenariusze przyszłych ujęć blokady, ale przede wszystkim, nawiązując do słów Jacka Leociaka, konstruowanie modelu rosyjskiej tożsamości w nowym stuleciu ${ }^{31}$.

\section{Bibliografia}

Adamowicz A., Granin D.: Księga blokady. Przeł. W. Bieńkowska. Warszawa 1982; wyd. II - 1988.

Adamowicz A., Granin D.: W oblężonym Leningradzie. Dramatyczne wspomnienia. Przeł. A. Wrzosek. Warszawa 2011.

Czyżowa J.: Hitler chciał pokonać Leningrad głodem i zimnem. A Stalin nienawidził tego miasta i nie pomógł oblężonym. „Gazeta Wyborcza” z 13 czerwca 2020 r. Dostępne także w Internecie: https://wyborcza.pl/magazyn/7,124059,26025505, hitler-chcialpokonac-leningrad-glodem-i-zimnem-a-stalin.html [data dostępu: 17.07.2020].

Czyżowa J.: Zakłamywana pamięć o tragedii i blokadzie Leningradu. „Plus Minus” z 14 września 2019 r. Dostępne także w Internecie: https://www.rp.pl/Plus-Minus/ 309139981-Jelena-Czyzowa-Zaklamywana-pamiec-o-tragedii-i-blokadzie-Lenin gradu.html [data dostępu: 17.07.2020].

Frejdenberg O., Pasternak B.: Na całe życie: listy 1910-1954. Przeł. W. Grajewski. Warszawa 2014.

Komisaruk E.: Blokada Leningradu i postpamięć w powieści Jeleny Czyżowej „Город, написанный по памяти”. „Przegląd Rusycystyczny” 2020, nr 3, s. 130-141.

Leociak J.: Osobliwe zrządzenie Opatrzności Bożej... Polska pamięć Zagłady w perspektywie katolicko-narodowej. „Teksty Drugie” 2016, nr 6, s. 122-152.

Lichaczow D.: Wspomnienia. Przeł. B. Żyłko. Warszawa 2016.

Mach A.: Świadkowie świadectw. Postpamięć zagłady w polskiej literaturze najnowszej. Warszawa-Toruń 2016.

Muchina L.: Dziennik czasu blokady. Zapiski nastolatki z oblężonego Leningradu. Przeł. A. Wołodźko-Butkiewicz. Warszawa 2014.

Oblężone. Przeł. A. Knyt, E. Milewska-Zonn. Wybór i oprac. A. Knyt. Warszawa 2011; wyd. II - 2013.

Pawletko B.: Blokada Leningradu i jej reprezentacje $w$ świetle innych doświadczeń granicznych. Katowice 2016.

Pawletko B., Waligórska-Olejniczak B.: Współczesne kino rosyjskie w obliczu traum wojennych. Kontekst literacki i kulturowy. Katowice 2020.

Peri A.: Leningrad. Dzienniki z oblężonego miasta. Przeł. G. Siwek. Kraków 2019.

Próchniak P.: Miejsca nieistnienia (wypisy). W: Pamięć i afekty. Red. Z. Budrewicz, R. Sendyka, R. Nycz. Warszawa 2014, s. 491-510.

${ }^{31}$ Zob. J. Leociak: Osobliwe zrządzenie Opatrzności Bożej... Polska pamięć Zagłady w perspektywie katolicko-narodowej. „Teksty Drugie” 2016, nr 6, s. 122. 
Przyślijcie cukierki. Z Julią Kantor, rosyjską historyczką i publicystką, rozmawia Justyna Prus-Wojciechowska. „Nowa Europa Wschodnia” 2014, nr 2. Dostępne w Internecie: http://www.new.org.pl/1798-przyslijcie-cukierki [data dostępu: 16.07.2020].

Reid A.: Leningrad. Tragedia oblężonego miasta 1941-1944. Przeł. W. Tyszka. Kraków 2012.

Sendyka R.: Miejsca, które straszą (afekty i nie-miejsca pamięci). W: Pamięć i afekty. Red. Z. Budrewicz, R. Sendyka, R. Nycz. Warszawa 2014, s. 285-307.

Tomczok M.: Czyja dzisiaj jest Zagłada? Retoryka - ideologia - popkultura. Warszawa 2017. Voroncova T.: Alexis Peri. The War Within: Diaries from the Siege of Leningrad. MA: Harvard University Press, 2017 [review]. „Laboratorium” 2017, nr 9 (3), s. 169-172.

Yarov S.: Leningrad, 1941-42: Morality in a City under Siege. Transl. A. Tait. Cambridge, UK-Malden, US 2017.

Алексеев А.: Человек, родившийся после войны, но эту войну переживший. http:// www.cogita.ru/a.n.-alekseev/andrei-alekseev-1/chelovek-rodivshiisya-posle-voinyno-etu-voinu-perezhivshii [12.07.2020].

Барскова П.: Блокадные после. Москва 2019.

Барскова П.: Живые картины. Санкт-Петербург 2014.

Барскова П.: Седьмая щелочь: тексты и судьбы блокадных поэтов. СанктПетербург 2020.

Блокада. Свидетельства о ленинградской блокаде. Хрестоматия. Сост. Полина Барскова. Москва 2017.

Дмитриев А.: Сведения и свидетельства: Сергей Яров - историк блокады. «Неприкосновенный запас» 2019, 5. https://magazines.gorky.media/nz/2019/5/svedeniyai-svidetelstva-sergej-yarov-istorik-blokady.html [21.07.2020].

Долин А.: На YоиТиве выходит «Праздник» - комедия про Новый год в блокадном Ленинграде. https://meduza.io/feature/2018/12/31/na-youtube-vyhodit-prazdnikkomediya-pro-novyy-god-v-blokadnom-leningrade-anton-dolin-rasskazyvaet-nadchem-na-samom-dele-smeyutsya-v-filme [28.07.2020].

Кто ел досыта в блокадном Ленинграде. https://zen.yandex.ru/media/news.ru/kto-eldosyta-v-blokadnom-leningrade-5c4dbc7b364f1f00acclcdec [28.07.2020].

Лаврентьева О.: Сурвило. Санкт-Петербург 2020.

«Они у меня в голове поселились и живут». Интервью Катерины Гордеевой с Сергеем Яровым. http://www.sinergia-lib.ru/index.php?page=yarov_s_v [21.07.2020].

Ушакин С., Махотина Е., Габович М., Ломагин Н., Хлевнюк Д., Киршенбаум Л., Сандомирская И.: Память о блокаде, блокада памяти. «Неприкосновенный запас» 2019, 5. https://magazines.gorky.media/nz/2019/5/pamyat-o-blokade-bloka da-pamyati.html [22.07.2020].

«Я все выдумал! И надеюсь, что имею на это право в нашей стране». Режиссер Алексей Красовский - о своей комедии «Праздник», действие которой происходит в блокадном Ленинграде. https://meduza.io/feature/2018/10/15/ya-vsevydumal-i-nadeyus-chto-imeyu-na-eto-pravo-v-nashey-strane [27.07.2020].

Яров С.: Блокадная этика. Представления о морали в Ленинграде в 1941-1942 г2. Москва 2013.

Яров С.: Повседневная жизнь блокадного Ленинграда. Москва 2013. 
Beata Pawletko - dr hab., prof. UŚ, rusycystka zatrudniona w Instytucie Literaturoznawstwa. Jej zainteresowania badawcze obejmują studia nad pamięcią i traumą w obszarze literatury oraz kultury rosyjskiej, ze szczególnym uwzględnieniem literackich, wizualnych i audiowizualnych reprezentacji Zagłady. Opublikowała trzy książki: Josif Brodski i Tomas Venclova wobec emigracji (2005), Blokada Leningradu i jej reprezentacje $w$ świetle innych doświadczeń granicznych (2016), Współczesne kino rosyjskie $w$ obliczu traum wojennych. Kontekst literacki i kulturowy (z Beatą Waligórską-Olejniczak; 2020). 